Article

\title{
Flagships of the Dutch Welfare State in Transformation: A Transformation Framework for Balancing Sustainability and Cultural Values in Energy-Efficient Renovation of Postwar Walk-Up Apartment Buildings
}

\author{
Leo Oorschot ${ }^{1}$, Lidwine Spoormans ${ }^{1}$, Sabira El Messlaki ${ }^{1}$, Thaleia Konstantinou ${ }^{1}$, \\ Tim de Jonge ${ }^{2}$, Clarine van Oel ${ }^{1}$, Thijs Asselbergs ${ }^{1}$, Vincent Gruis ${ }^{1}$ and Wessel de Jonge ${ }^{1, *}$ \\ 1 Department of Architectural Engineering/Technology, Faculty of Architecture and the Built Environment, \\ Delft University of Technology, Julianalaan 134, 2628BL Delft, The Netherlands; \\ 1.m.oorschot@tudelft.nl (L.O.); l.g.k.spoormans@tudelft.nl (L.S.); s.elmesslaki@tudelft.nl (S.E.M.); \\ t.konstantinou@tudelft.nl (T.K.); c.j.vanoel@tudelft.nl (C.v.O.); m.f.asselbergs@tudelft.nl (T.A.); \\ v.h.gruis@tudelft.nl (V.G.) \\ 2 HU University of Applied Sciences Utrecht, Padualaan 101, 3584CH Utrecht, The Netherlands; \\ t.dejonge@winket.nl \\ * Correspondence: w.dejonge@tudelft.nl
}

Received: 29 May 2018; Accepted: 17 July 2018; Published: 21 July 2018

\begin{abstract}
Increasing energy efficiency of the housing stock is one of the largest challenges in the built environment today. In line with the international Paris-Climate-Change-Conference 2015, Dutch municipalities and housing associations have embraced the ambition to achieve carbon neutrality for their social housing stock by 2050 . However, most deep renovation designs for increasing the energy efficiency of dwellings focus on the relatively easy portion of the housing stock: postwar row housing. Furthermore, such design solutions are mostly produced without much care for architectural quality and cultural heritage, nor for testing for consumer preferences. Yet, such aspects are of major importance in tenement housing, particularly regarding the architectural quality of the huge numbers of walk-up apartment buildings from the inter- and postwar periods owned by housing associations in the larger cities. Renovation of buildings of this typology is more complex because of, among others, technical, social, and heritage factors. To support decisions in this complex context, a General Transformation Framework and a Roadmap has been developed for generating design solutions for deep renovation of representative parts of postwar walk-up apartment buildings with the aim to increase energy efficiency; retain its architectural legibility and cultural heritage value; and allow for the presentation of (end) users, with various options for adaptation to assess their preferences.
\end{abstract}

Keywords: walk-up apartment buildings; affordability; postwar; carbon neutrality; energy efficiency; architectural values; cultural values

\section{Introduction}

\subsection{Carbon Neutrality by 2050}

Increasing energy efficiency of our housing stock is one of the largest challenges of the built environment today - a challenge that has been embraced in the Netherlands, as well as many other countries. In line with the international Paris-Climate-Change-Conference 2015, Dutch municipalities have embraced the ambition to achieve carbon neutrality for the social housing stock by 2050 . 
According to the European Energy Performance of Building Directive (EPBD) [1], by 2020 all new buildings must meet the 'BENG'-norm, meaning that they must be almost energy neutral [2]. Dutch housing associations organisation Aedes has promised that their average affordable housing stock is going to have Energy Performance Certificate (EPC) label B by 2021 [3]. The recently published 'housing agenda' 2017-2021 of Aedes promises a carbon neutral housing stock for all Dutch housing associations by 2050 [4]. In recent years, many concepts and design solutions have been developed for energy efficient retrofitting of the (Dutch) housing stock [5]. These solutions target different levels of energy efficiency using insulation alone, ranging from small upgrade of the energy label, most commonly up to label B, to achieving zero-energy demand, referred to as Nul-op-de-meter NOM. However, most of these solutions focus on the relatively easy part of the housing stock: row-housing. This can be partly explained by the huge share of terraced housing in the Netherlands (70\%) and the fact that these dwellings are (technically) relatively easy to renovate on a one by one basis. Recent research has also shown that current design and implementation processes are very often fragmented and not efficient [6]. Although there are some examples of projects trying to minimize construction time along with energy reduction, using methods such as prefabrication of the components, a deep renovation in inhabited state is possible. At the same time, current design solutions are not transferable to significant parts of the housing stock in larger cities. For example, approaches that have recently been developed for row-housing emphasize a 'one stop shop' approach in which individual dwellings are renovated within a few days to the level of zero energy use [7]. For other parts of the housing stock, other approaches may be more have proven to be more effective, ranging from more intensive approaches (e.g., block by block renovation) to less intensive approaches, such as applying 'slow architecture', in which the energy efficiency and architectural quality of dwellings are gradually increased over a number of years. Moreover, current design solutions are mainly supply-driven, being developed by contractors for professional clients (mainly housing associations). Demand preferences and cultural heritage values that play a particularly important role in the transformation of the older parts of the housing stock in the larger cities are not explicitly addressed in the design process or in the choice of design alternatives [8]. There is still a lot of research to be done, especially for walk-up apartment buildings, which constitute an important part of the stock, although it is particularly challenging to make them carbon neutral. Particularly in the larger cities, there is a major challenge to create attractive and feasible design solutions or strategies to walk-up apartment buildings.

\subsection{Integrated Appraoch}

In response to the problem in current practice as described above, energy efficient renovation is not only to be viewed as a technological challenge but as an architectural and social challenge as well. Many of the more complicated parts of the housing stock, particularly in the larger cities, have specific architectural, urban, and cultural heritage qualities that can be retained or ruined by deep renovation. Moreover, the legibility of architecture or cultural heritage values is not always taken into account in design solutions that have been developed by contractors or housing associations. In developing solutions, a major design challenge is to find an architectural balance between existing and newly added qualities when designing the renovation of housing blocks with specific architectural heritage values. Such a balance can be found through a careful analysis of the architectural and cultural value of the existing, original building, by recording which characteristics must be preserved and which may be modified in order to improve the technical performance of a building. Newly added materials and components often affect the original appearance. Replacement components with larger dimensions, featuring different materials or textures, may have major implications for the overall image of the building. Newly added materials and components often affect the original appearance. Replacement components with larger dimensions, featuring different materials or textures, may have major implications for the overall image of the building. Figure 1 shows four examples of successful deep renovations.

The use of design tools is necessary to make balanced choices about which solutions best fit in the structure of the building, weighing needs of users and owners but also principles associated with the 
architectural appearance or even culture-historical values of the building in relation to its environment. Furthermore, in case of energy efficient renovation, climate measures such as heating and cooling, solar shading, and ventilation have to be carefully integrated into the total design, technically as well as architecturally. Therefore, our research is both technically and conceptually oriented. On the one hand, it begins with the technical requirements of effective designs for increasing the energy efficiency. On the other hand, its primary concern is incorporating architectural quality, as well enabling testing for consumer preferences as a means to evaluate design solutions. Through ex ante testing for consumer preferences, design models can be developed that are most likely to be adopted by the market.
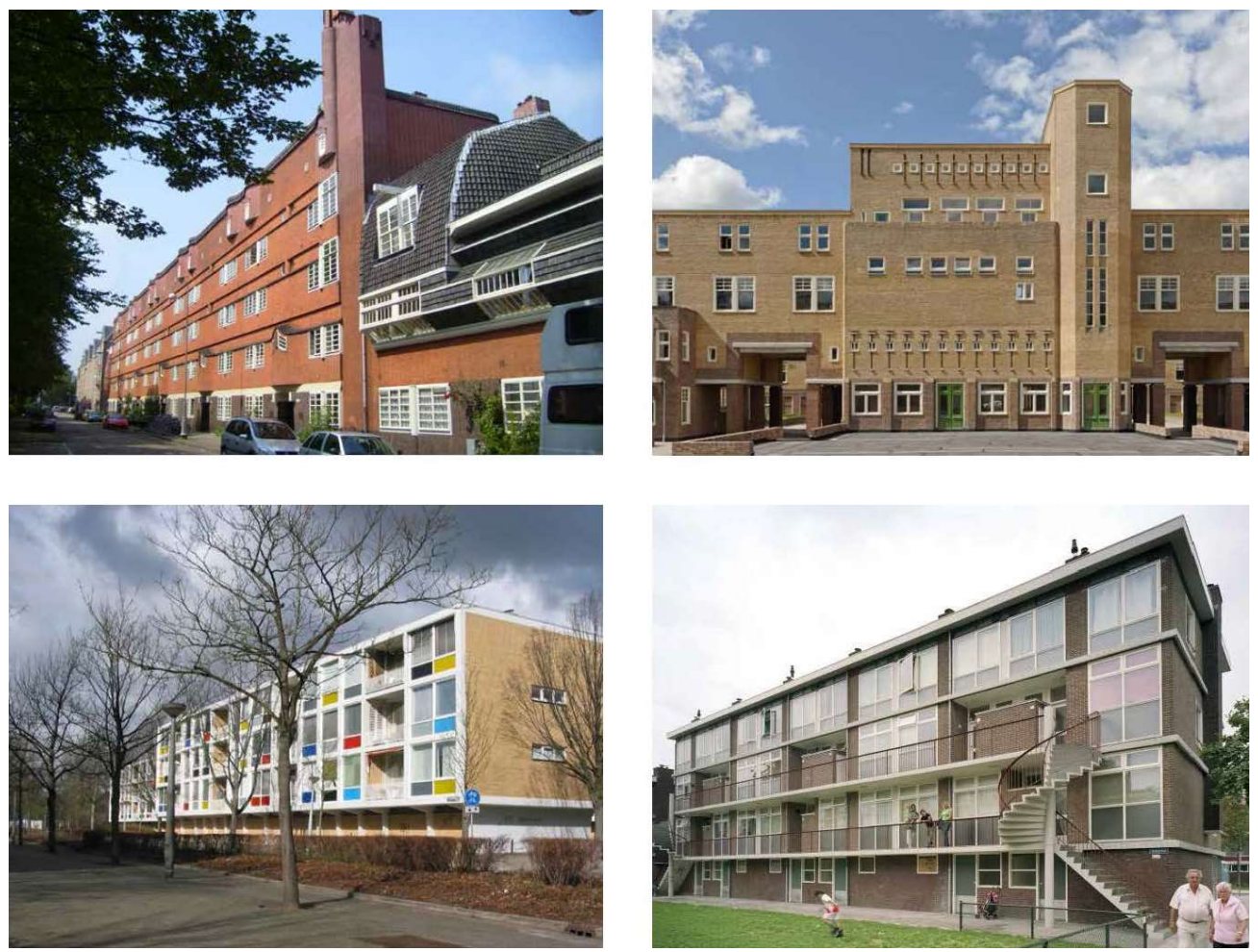

Figure 1. Walk-up apartment buildings are the flagships of the Dutch welfare state and icons of modern architecture. Top left: Het Schip Spaarndammerbuurt Amsterdam (1914-1921), architect Michel de Klerk (1884-1923). Top right: Justus van Effencomplex Spangen Rotterdam (1922), architect Michiel Brinkman (1873-1925). Bottom left: De Verfdoos Slotermeer Amsterdam (1956), architect Allert Warners (1914-1980). Bottom right: Robijnhof Utrecht (1956), architect Gerrit Rietveld (1988-1964). Pictures are from the municipal picture data banks and architects.

To help address the challenge above, this article presents the development of a General Transformation Framework (GTF) of postwar walk-up apartment buildings, which allows for the development of design alternatives for energy efficient retrofitting, taking into account architectural heritage values, as well as enabling testing for consumer preferences and a Roadmap of interventions of this housing stock. The article starts with a general description of the object of our research: the characteristics of the buildings (including cultural and architectural values) and challenges (particularly concerning energy efficiency) of walk-up apartment buildings. Subsequently, we discuss the GTF, which combines energy efficiency measures with design solutions that respect the architectural values of these buildings. We illustrate how this GTF can be used by generating alternative design solutions for one exemplary case. Finally, we discuss the results of a validation session of the GTF and the questioners list with architects and representatives from client housing associations and present a Roadmap as our conclusion. 


\subsection{Research Framework}

There are many studies dealing with deep renovation or energy efficiency of walk-up apartment buildings, usually done by housing associations, consultancies, or institutes like TU-Delft. There are inventories of neighbourhoods with walk-up apartment buildings dealing with the urban and architectural qualities. There are architectural assessment methods developed by the Cultural Heritage Agency and the municipality of Amsterdam [9-11]. Additionally, there are studies about the experience of inhabitants during the transformation of these neighbourhoods [12,13]. However, these studies usually focus on one of the issues: refurbishment, heritage, or people.

The University of Technology Eindhoven published some promising articles with an integral approach [14,15], building on Elkington's [16] people, planet, and profit. Different areas of sustainability in the built environment are defined as economic, social, and environmental.

However, rapid developments in society are changing the ambitions of municipalities and the state. The carbon neutrality of the housing stock and construction industry is currently the most important challenge. Older studies usually focused on the energy demands of the housing stock.

Another issue is the locality and contextual circumstances to solve the problems of energy efficiency. Studies from abroad are difficult to use in this research. Contextual parameters such as policy of municipalities on the energy transition, changing Dutch laws and bylaws on energy and housing, and the local situation on the housing marked are difficult to compare. It is probably for this reason that one of the best studies in this field in not translated [17,18]. It is an inventory about walk-up apartment buildings and deep renovation guidelines by the Dansk Bygningsarv. Heritage and energy efficiency are combined with smart solutions. However, this study has his limits; it only focuses on postwar Danish brickwork architecture, and consumer preferences are not taken into account.

Building on these article and books, the aim of this article is to develop GTF of the post war walk-up apartment buildings, a framework of feasible interventions regarding energy efficiency, architectural qualities and consumer preferences, and an ideal model or Roadmap [19,20].

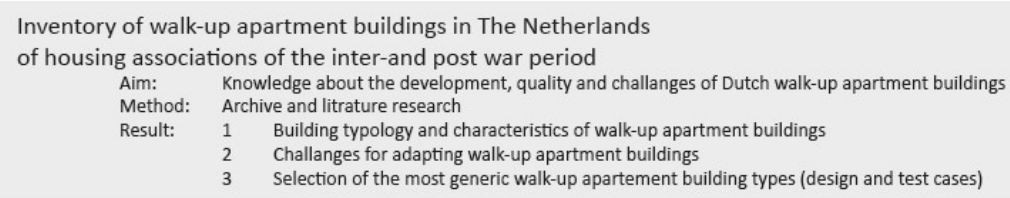

Figure 2. Research framework RTD. This article summarizes the characteristics of the walk-up apartment buildings and describes the research process and results of postwar walk-up apartment buildings; the research of the interwar walk-up apartment buildings will be published by 2019 .

The method to achieve this goal is Research through Design (RTD) [21-23]. Figure 2 shows the different steps in the research. RTD is a scientific inquiry with deep renovation proposals that takes advantage of the unique insights gained through design practice to provide a better understanding of complex transformation and intervention issues. This is a multi-disciplinary research with different fields of knowledge and methods. Attractive and feasible design alternatives are produced for renovation of a selection of housing types that represent a relatively large proportion of postwar walk-up apartment 
buildings. These designs are categorized in a GTF and are used in the questionnaires. The design alternatives are tested for user preferences by employing a discrete choice modelling method, resulting in design solutions (roadmap) that are likely to be accepted by users. Both design and research are activities that are typically initiated for a contextually situated purpose. In summary, the problem is the fragmentation of knowledge and lack of design solutions to increase the energy efficiency and architectural quality of this housing stock, as well as the lack of insight into how the market will respond to various design alternatives - the latter being caused to a large extent by lack of empirical evidence, thereby increasing the need for testing consumer preferences on the basis of artefacts. In RTD, the case study is an empirical inquiry that investigates a phenomenon within the real-life context; this provides multiple sources of evidence and the opportunity to generalize a theory. Design alternatives are ideas and were developed for the renovation of the most generic walk-up apartment building and tested for user preferences with questionnaires. This RTD method is necessary to develop the GTF, amid real-life conditions. Validation of the GTF and the design strategy will be done with test cases in collaboration with housing associations and architects. This method makes it possible to recapitulate the research.

\section{Overview and Characteristics of Walk-Up Apartment Blocks from Inter- and Postwar Period}

\subsection{Walk-Up Apartment Building Inventory Framework}

The aim of walk-up apartments in the Netherlands was to provide affordable housing in the rapid growing urban regions in inter- and postwar period. The walk-up apartment building is one of the flagships of the Dutch welfare state, provides many people with an affordable apartment in the city regions, and is in built in huge amounts. As pointed out, there are already good overviews dealing with social housing in general [24] and different municipalities [25-30]. There are inventories of municipalities and neighbourhoods [31-34]. Building on the cultural and architectural framework of Cultural Heritage Agency and the municipality of Amsterdam, buildings criteria were developed that required the development of a typology and GTF.

- Cultural, historical, and urban context.

- Variations of indoor environments and floorplans (woontechnisch).

- Construction techniques, materials, and amenities in the apartments (bouwtechnisch).

- Institutes and persons of significant meaning.

- Policy, protocols, laws, and bylaws of significant meaning.

- Intentions of stakeholders (architects, institutes, municipalities).

The goal of this inventory framework is to identify the different building types of the Dutch walk-up apartment building family and to describe the characteristic floorplans, construction techniques, materials, and intentions of stakeholders. This data is necessary for developing the GTF, and collecting quantitates data with questionnaires about consumer preferences in relation to the refurbishment and architectural qualities.

\subsection{Overview and Typology}

Dutch walk-up apartment buildings of the postwar period are mostly owned by housing associations, and the interwar apartments are partly owned by housing associations or by the inhabitants. The majority was built during two periods: between 1916 and 1926 (the interwar types) and between 1946 and 1965 (the postwar types). These time frames are related to several protocols like the Housing Act of 1901-1902, municipality building bylaws, and laws about financing dwellings. Today, 2016, in the Netherlands there are still 799,56 apartments of all types from the period 1906-1965 left. That is about 10.47 percent of the current Dutch housing stock. In Amsterdam there are still 155,456 apartments (36.6\%), in Rotterdam 104,014 (33.4\%), in Den Haag 107,253 (42.4\%), and in Utrecht $29,482(19.7 \%)$ [35]. This adds up to about 400,000 apartments in the four cities (we assume the most of these buildings have walk-up apartments). 
Social reformers had a great influence on the design of these floorplans. For example, the bed cabinet (alkoof) that was still often used in the ninetieth century became prohibited. Parents and children got separated bedrooms $\left(9-10 \mathrm{~m}^{2}\right.$ and $\left.5 \mathrm{~m}^{2}\right)$ and, if possible, also girls and boys had separate bedrooms. The kitchen was separated from the living and became a space for just preparing food, not for having dinner, like farmers would. For that reason the kitchen was between 5 and 6 square meters and directly connected to a shallow balcony at the garden side, as well as a laundry space. The balcony was used to dry clothes and featured storage space in an outside cabinet [24].

The postwar subtypes are again derived from the interwar types. The most successful postwar floorplan in the categories piled, poured, or dry prefabricated construction methods, which was adopted for about 40.9 percent of all social housing units of the era, was Keuzeplan P45.001 or type E3, designed by the architect E.F. Groosman (1917-1999). The success of type E3 was based on the required housing differentiation by municipalities. Type E3 has two and three bedroom variations. About 80 percent of the apartments have more or less the same size and spatial arrangement with two or three bedrooms and an average of 50-70 square meters of useful floor area. Municipalities usually require buildings with apartments: 10 percent one bedroom, 40 percent two bedrooms, 40 percent three bedrooms, and 10 percent had more than three bedrooms. There was not much differentiation of floorplans of walk-up apartment buildings in the postwar period [24,36].

Despite many similarities, there are also important differences between walk-up apartment buildings that need to be mentioned. Figures 3 and 4 show the different apartment buildings types from the Netherlands. On the basis of the inventory, four subtypes of buildings can be defined:

1. Interwar buildings using traditional construction methods from Amsterdam, similar to building types of the European metropoles of the nineteenth century;

2. Interwar buildings using traditional construction methods from Den Haag, derived from the traditional Dutch boven-beneden-woning from the fin siècle, with two apartments on top of each other, each with its own entrance door;

3. Postwar buildings using mixed construction methods, i.e., traditional (brickwork loadbearing walls, and façade) and prefabricated construction components (foundation piles and beams, floor elements, and stairs);

4. Postwar buildings using construction systems, i.e., the dry assemblage of prefabricated construction components.
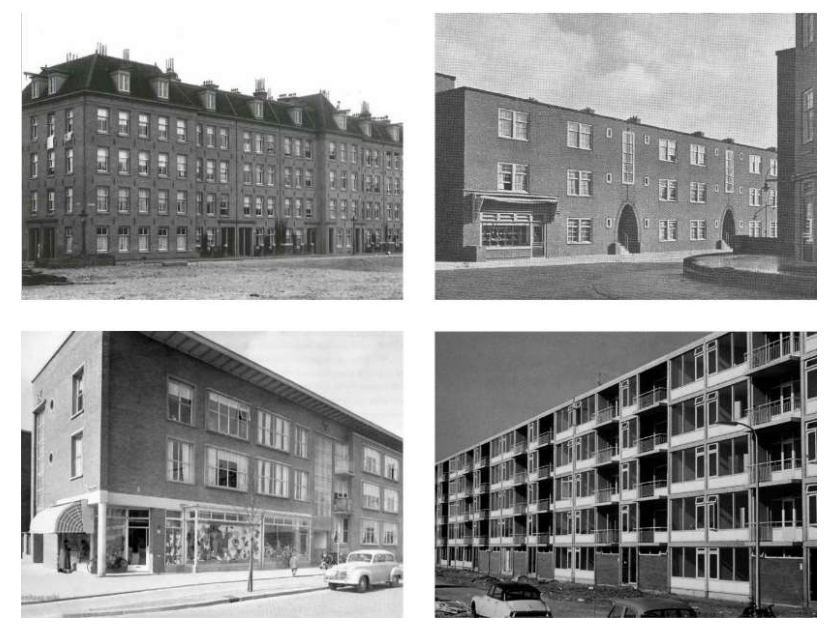

Figure 3. Four subtypes. Top left: subtype 1 interwar traditional construction methods Amsterdam. Top right: subtype 2 interwar traditional construction methods Den Haag. Bottom left: subtype 3 postwar mixed construction methods. Bottom right: subtype 4 postwar construction systems. Pictures are from the municipal picture data banks of Den Haag Amsterdam and Utrecht. 

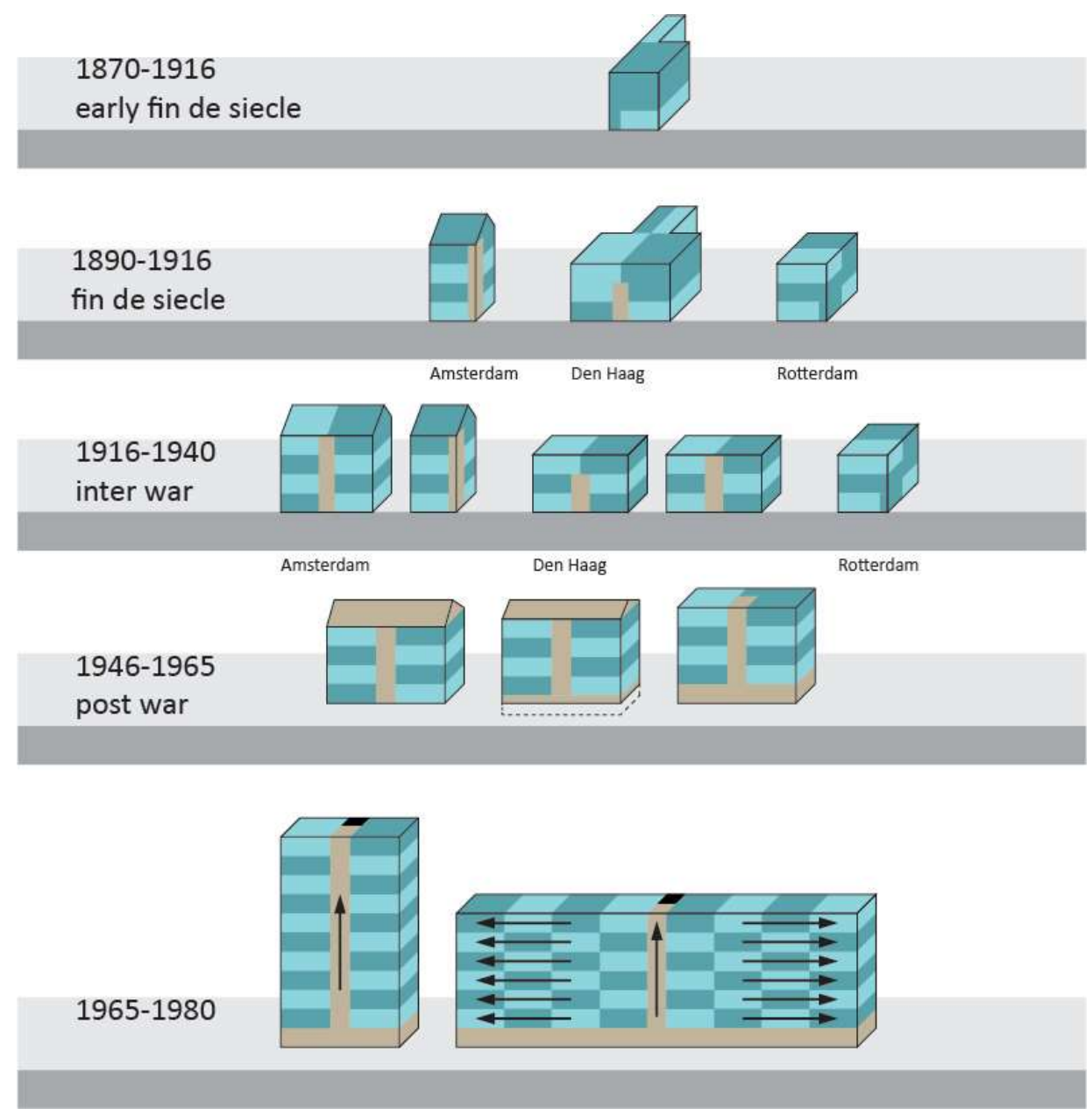

Figure 4. Typology of the Dutch tenement apartment building. Graphic by Leo Oorschot.

\subsection{Interwar Walk-Up Apartment Buildings}

The interwar walk-up apartment buildings are usually part of a perimeter city block of three to four storeys, and the façade was on the building line. Buildings are directly following the carefully designed urban spaces. For that reason, the blocks could be folded or irregular, leading to exceptions in the floorplans of corner apartments. The gardens inside the blocks are usually private, although some are known to be collective, and balconies are shallow. All storeys, including the plinth, feature dwellings [37-40]. In Amsterdam there are usually four stacked units located on a closed stairwell and sharing one service shaft. The four-storey volumes have an urban character, typically featuring a pitched roof over an attic with storage space [27,41-43]. In Den Haag there are usually six units located around an open stair well and two service shafts. The blocks have a flat roof and, usually, three storeys, and are less urban in their scale and architectural character [28,29,36,44]. In Rotterdam, a somewhat similar type was used, but the bedrooms of all apartments were located on the top floor under a flat roof. These types have three or four storeys and usually feature deep apartments, because each apartment has its own staircase to the bedroom floor $[45,46]$. In both cities, the front door was supposed to be directly at the street (Rotterdam) or at least in the open air (Den Haag). In the interwar period, about 35 percent of the apartments had one bedroom, 31-34 percent two bedrooms, 21-25 percent three bedrooms, 6 percent four bedrooms, and 2-4 percent more than four bedrooms [36].

The buildings have a traditional construction system with brickwork loadbearing walls and façades, floors made of fir beams and boards, and windows and doors made of pine. The foundations, which are usually supported by wooden piles, are mostly made of brickwork and, occasionally, in 
Amsterdam, of reinforced concrete. In Den Haag, the foundations are directly embedded in the sand [47]. The buildings feature basic service systems: usually a coal stove or sometimes block heating and natural ventilation depending on brickworks shunts and operable windows. In the sixties and seventies of the past century, all the apartments were provided with their own central heating with natural gas.

The architecture of these buildings is mostly referred to as Dutch brickwork rationalism, usually a simple brickwork façade with openings for windows and doors inspired on the ideas and works of H.P. Berlage (1856-1934) about a collective architecture. In architectural terms, Den Haag referred to the so called New The Hague School and Amsterdam to the expressionism of the Amsterdam School, although-despite some exceptions-these styles were associated with the more expensive buildings for middle and upper class families. The affordable walk-up apartment buildings of housing associations had usually a restrained architectural expression. Amsterdam and Den Haag played an important role in the development of the interwar types. Both municipalities had social democratic dominance in the City Council and Administration. Directors of the town planning and housing departments of these cities were important social reformers and introduced several bylaws. In Den Haag this was P. Bakker Schut (1877-1952), and in Amsterdam A. Keppler (1867-1941) [27,29].

\subsection{Postwar Walk-Up Apartment Buildings}

In 2016, in the Netherlands there are still 409,363 apartments of the postwar period 1945-1965 left. That is about 15.1 percent of the current Dutch housing stock. In Amsterdam, there are still 39,465 apartments (10.6\%); in Rotterdam, 40,715 (17.4\%); in Den Haag, 37,831 (19\%); and in Utrecht, $15,076(17.9 \%)$ [35]. This is about 133,087 apartments in the four cities; we assume that most of these buildings have walk-up apartments. In the postwar period, about 55 percent of the housing production was subsidized and built by housing associations and municipalities [24].

The postwar walk-up apartment buildings are usually linear buildings of four to five storeys with four to eight stair wells each with eight apartments and a shared front door. The ideal orientation of the buildings is north-north-west to south-south-east with the living oriented towards the sun (west to south side) and the kitchen and stair well at the shadow-side (the east to north). However, only as an exception, the buildings were all oriented on the sun; usually they are efficient urban ensembles such as open urban blocks with four to eight linear buildings around a semi-public court yard, in spite of the CIAM ideals about the sun. Buildings are built-to line of the expansion plan and usually have a front garden. There are usually eight apartments in two stacks of four units around a closed stair well. Roofs are often flat or slightly pitched, and storage space is provided in the (half) basement, and later at the ground floor $[27,29,36]$. The image of the architecture developed from the early to the late postwar period was defined by cities and limited by the National State. The directives for the architectural design of buildings were usually described in architectural guidelines as an annex to the urban expansion plans. City Councils and Administrations approved these plans and guidelines and nominated supervisors to control the architectural quality. As Figure 5 shows the first period expensive ceramic products such as roof tiles and brick for garden walls were used, sometimes with ornaments and beautiful entrances with window frames to the roof. Later, flat or shed roofs with bitumen roofing became more common, garden walls disappeared, and window frames spanning from floor to floor were introduced to avoid expensive brickwork spandrels and concrete panels in the façade. The change in architecture was the consequence of directives from the ministry about reducing cost by avoiding expensive materials (ceramic); a lack of skilled labour; and new ideas about modern architecture, standardisation, and industrialisation [24,48].

In the early postwar period, the heating was originally based on coal-fuelled stoves or district/block heating, and there were no ventilation systems. In the sixties and seventies of the last century, the heating system was changed into central heating with natural gas. After the energy crisis in the seventies, single glazing was increasingly replaced by insulating glass units, often calling for the simultaneous replacement of window frames. The improved air-tightness of the new windows and doors necessitated the introduction of mechanical ventilation systems. In the period 1946-1965, there were 235,000 apartments 
(53.4\%) built by small and middle contractors with a mixed construction method: traditional brickwork loadbearing walls and façades combined with prefabricated construction components for foundation piles and beams, floors, and stairs). Between 1948 and 1961, about 205,000 apartments (46.6\%) were built by larger contractors, introducing more complex building methods and construction systems like Airey (from the UK), Korrelbeton, RBM I, Rottinghuis, Bakker, Muwi, Pronto, VAM, BMB (from the UK), Coignet (from France), and Elementum Larsen \& Nielsen (from Denmark). These construction methods are usually divided in three categories: piled, poured, or dry prefabricated, all of which were for exclusive use by licensees [49]. Because of the demand of houses, municipalities like Amsterdam, Rotterdam, Den Haag, and Utrecht entered into direct agreements with construction companies regarding massive and continuous construction flows, the so-called continucontracts. Some of these contractors became licensees for foreign construction systems featuring the dry assemblage of mass-produced prefabricated components. To avoid high transport costs between the factory and the building site, local production was set up, and, consequently, most methods are linked to specific city regions. These buildings have an industrial expression that is linked to the postwar period. After a change of the conditions for financing social houses in Voorschriften en Wenken of 1965, elevators became obligatory for apartments with a floor above $11.20 \mathrm{~m}$. Only a walk-up apartment building of three storeys without a storage space on the ground floor was possible, which rendered the walk-up tenement apartment building no longer feasible [48]. This triggered a new suburban building type: the galleried apartment building or flat, which usually features around ten storeys, new service and construction technology, and multiple elevators.
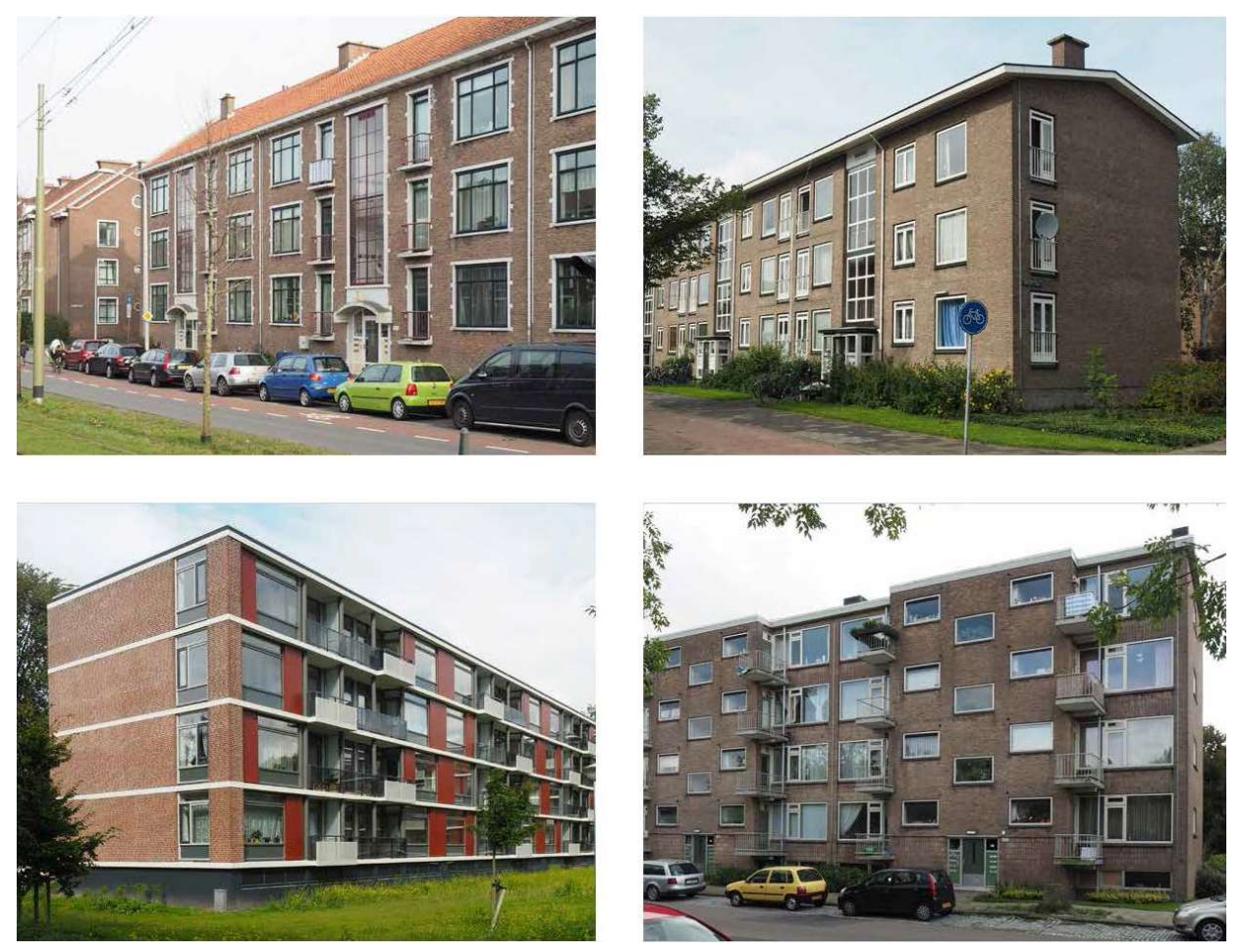

Figure 5. Walk-up apartment buildings in Den Haag owned by housing associations. The change in architecture was the consequence of directives from the ministry about reducing cost by avoiding expensive materials (ceramic); a lack of skilled labour; and new ideas about modern architecture, standardisation, and industrialisation. Top pictures involve early postwar architecture from the neighbourhood Moerwijk, and bottom pictures show late postwar architecture from the neighbourhood Mariahoeve. The pictures on the left involve the Muwi construction system, and the pictures on the right show the Korrelbeton system. Only in some specific cases (Airey, Coignet) is there a clear relationship between architecture and construction system. Pictures by Leo Oorschot. 


\section{Challenges for Adapting Walk-Up Apartment Buildings}

\subsection{Deep Renovation in Uninhabited or Inhabited State}

In the past, several assessments about the quality of walk-up apartment buildings and the possibilities of adapting this housing stock have been pursued, but with a different focus. Various problems were identified in the past and described by researchers dealing only with postwar walk-up apartment buildings, usually in uninhabited state [50-53]. In structural terms, there are principle differences between inter- and postwar tenement blocks. In the interwar period, the loadbearing masonry walls and façades provided stability to the buildings. However, the dimensions of the loadbearing parts are minimal, prohibiting the addition of extra weight on top. Brick walls and facades are easily damaged by vibrations of heavy traffic and salt. Due to the wooden floors, the fire and smoke resistance between the apartments is poor, as is the sound-proofing. Postwar buildings on the other hand typically have reinforced concrete loadbearing frames, including concrete floors and roofs, reducing such problems. The concrete roofs are usually lighter, with less reinforcement, and have a limited loadbearing capacity. These different characteristics naturally lead to different current strategies for deep renovation [54-56]. The interwar subtypes with brick walls and wooden floors are mostly refurbished according to the box-in-box renovation method, and in an uninhabited state structural repair of brickwork and foundations makes this necessary. This intervention is expensive, partly because the inhabitants need to be compensated for moving house. Street façades are usually renovated to their original appearance. Usually, the floorplans are renewed. Fire and smoke protection and noise reduction techniques between apartments are applied. Outdated service systems, pipes, and ducts are replaced, and asbestos is removed. Kitchens, bathrooms and toilets are renewed. The interwar Amsterdam subtype could add about 20 percent of useable floor space under the pitched roof, which would make the deep renovation less expensive. The interwar Den Haag subtype does not have that possibility. Some postwar construction systems like Airey also have wooden floors and are renovated following the box-in-box method as well. In postwar apartment buildings, often the building skin is refurbished to comply at least with energy label B, and the kitchen, bathroom, and toilet equipment's are replaced. However, deep renovation in inhabited state is nowadays necessary because of the stagnation of tenant mobility of the last years. This is only possible with postwar apartment buildings.

\subsection{Stagnation of Tenant Mobility and the Necessity of Renovation in Inhabited State}

The change of the Housing Act of 1 July 2015 had a profound influence on the renovation of the housing stock. Before the economic crisis and the announcement of the new Housing Act, housing associations emphasized a demolition and replacement approach for many four storey apartment blocks, among others, as part of their objectives to stimulate differentiation in household income in neighbourhoods. Between 1995 and 2015, housing association built, usually, 30 percent units for lower income and 70 percent for other income groups. The Housing Act, however, stimulates housing associations to focus their activities on the lower income households, so they now try to maintain affordable housing stock and emphasize renovation strategies instead of demolition. Moreover, the high pressure on the housing market in larger cities makes it difficult to move out tenants for renovation and demolition purposes. The current stagnation of tenant mobility and the need for affordable dwellings is an important reason to develop renovation strategies that are possible while inhabitants stay in their apartment.

\subsection{The Impact of the Energy Transition}

As pointed out, one of the key challenges is energy efficiency of apartment buildings. Residential energy consumption has two components. The energy demand related to heating or cooling depends on the level of insulation of the skin of the building, the EPC. The energy demand related to the behaviour and size of the household. A household with children is using much more hot domestic 
water than someone who lives alone. Because of the shape of the buildings, there is not much space on the roof to have PV-panels or Solar Collectors; therefore, apartment blocks always need an external renewable energy source for heating or cooling. In the Dutch situation, the carbon footprint of construction or material is not yet taken into account; only the use of energy is supposed to be carbon neutral by 2050 and renewable. In the Metropole Region Amsterdam [57] and Metropole Region Rotterdam and Den Haag [58] and the Region Utrecht [59], the old gas networks from the period 1963-1968 are removed, and the existing district heat network will be extended and connected to a large open regional heat network. However, in most scenarios of the government and Dutch institutes, there will be a mix of systems to provide heat to dwellings by 2050 [60-65]:

1. Regional and open heat network $\left(70^{\circ} \mathrm{C}\right)$ sources are industrial waste energy (EfW), geothermal energy (BTES), aquifer thermal energy storage (ATES), and biomass.

2. All electric building and smart grid with renewable electricity. Sometimes it is in combination with individual heat pomp $\left(50^{\circ} \mathrm{C}\right.$ or $\left.70{ }^{\circ} \mathrm{C}\right)$ on the roof, with air as heat source.

3. All electric building and smart grid with renewable electricity, in combination with collective building heat network $\left(50^{\circ} \mathrm{C}\right.$ or $\left.70^{\circ} \mathrm{C}\right)$ and seasonal thermal energy storage (STES).

In the Heating Act (2014), no regard was given to the position of housing associations as regards the heating of their buildings, heating supposed to be provided by the free market. However, in the older Tenant Act, the position of housing associations in providing heat to tenants was already described. Since 6 March 2018, the government has decided to change the Heating Act, and housing associations will be excluded.

A problem is that the EfW is not carbon neutral; there is only the promise that EfW is replaced by BTES or ATES by 2050. Another problem is that a heat network only delivers heat, and in the case of a geothermal energy after about 30 years, the temperature is to low, and possibly a new heat source is needed. Furthermore, during the year, the demand of heat is low in the Dutch climate zone; only in winter time there is a peak in the demand. The dimensions of the heat network are designed to deliver only in the winter peak; therefore, the investments are enormous, and it is still unclear who will be investing in these heat networks. In the end, tenants will pay for the expensive new infrastructure. The most efficient way to provide heating and cooling is with electric buildings with smart grid and block heating with seasonal thermal energy storage STES, low temperature heating LTH, and apartments with a low energy demand (label A/B) [66]. For residents, this is the most advantageous option, since it means a low energy bill for tenants and higher investment costs for housing associations. However, a problem is the capacity of the smart grid at the moment. The most likely option is a regional open heat network. In the municipality of Den Haag, this has been already decided concerning the postwar neighbourhoods $[67,68]$.

\subsection{Architectural Value of Postwar Walk-Up Apartment Buildings}

In the GTF, architectural quality is partly a starting point and partly an option in terms of consumers' preferences. In Amsterdam and Den Haag, most interwar neighbourhoods are protected by the municipality. Some interwar neighbourhoods in Amsterdam are protected by the state. According to the method developed in municipality of Amsterdam and the current practice, only the façade is taken into account as heritage. In by the municipality heritage-protected neighbourhoods (gemeentelijk bescherm stadsgezicht), only the street façade is protected. And regard is not given by housing association to the quality of floorplans, details, materials of the interior such as woodworks of doors and doorposts or cabins, and the façade on the garden side. Postwar neighbourhoods are only in some exceptional cases protected by municipalities. We identified distinguishing characteristics of each of the four subtypes.

All interwar types have a brickwork façade with windows. The Amsterdam buildings have a real urban character with four stories, vertical lines, and a closed staircase with, usually, four apartments and an impressive roof (subtype 1). The social housing was usually in simple brickwork rationalism, 
and the more expensive buildings are in the style of expressionistic Amsterdam School architecture. The Den Haag/Rotterdam types usually have three and, sometimes, four stories and a flat roof (subtype 2). In the interwar period, there was a bylaw that all front doors must be direct on the street in open air. The Den Haag types have a building depth of about $10 \mathrm{~m}$; the apartments on the 2e and 3e floors have their front door in an open stair case on the first floor. Usually, the architecture is in simple brickwork rationalism, and sometimes in beautiful Haagse School architecture. Rotterdam types have a depth up to $15 \mathrm{~m}$, because each apartment has its own stair case. Architects from Amsterdam, Den Haag, and Rotterdam are working in all municipalities, and there was lot collaboration. The differences between these characteristics were due to local bylaws. As pointed out, in Amsterdam, Rotterdam, and Den Haag, only street façades are protected with regard to heritage aspects, not interior and garden façades with shallow balconies.

In the postwar period, there are two main types: buildings using mixed construction methods (subtype 3) and buildings using construction systems, i.e., the dry assemblage of prefabricated construction components (subtype 4). The urban plans of the postwar period are different. Buildings are solitary objects in ensembles. Subtype 3 is usually brickwork buildings with a fenestration of windows and doors, which, in the beginning, have roofs with tiles and, later, flat or mono-pitched roofs with a cheaper bituminous material. As pointed out, the quality of the architecture was defined in guidelines of each architectural expansion plan and implemented by a supervisor. Subtype 4 is what many people recognize as real postwar architecture with a rational or industrial character. Brickwork and pitched roofs have almost disappeared and concrete construction elements and window frames floor to floor appear. In particular, this industrial characteristic has cultural and architectural value; in Amsterdam, with the Airey-buildings; in Den Haag and Groningen, with the neighbourhood with Rottinghuis buildings; and in Utrecht, with the VAM-buildings.

In the Beauty of Amsterdam, the municipality of Amsterdam is using an architectural value assessment with the parameters: urban ensemble quality and architectural quality of the building of inter- and postwar period [11]. They are divided into four categories: basic, C, B, and A. Basic has low urban quality, category $C$ is in a characteristic area and has an urban quality, category $B$ is in a protected area with protected street facades, category A is a highly protected neighbourhood, and all buildings are supposed to be conserved with a refurbishment. The design and test cases of the interwar period in our GTF are all in a category B area. Renovation architect Gert Jan te Velde made a scheme to assess small renovations. In summary, in the GTF we consider the street façade as an important part of a highly esteemed urban ensemble.

\subsection{Starting Point of the GTF}

In the herein reported development of GTF, we have been focusing on the postwar walk-up apartment buildings subtype 4 , buildings with characteristic façades using construction systems, i.e., the dry assemblage of prefabricated construction components. Starting points have been the current renovation strategies, lack of tenant mobility, and decisions made (or likely to be made) by municipalities about heat networks.

\section{General Transformation Framework (GTF) of Postwar Walk-Up Apartment Buildings}

\subsection{Triple Bottom Line: Planet, Profit, and People}

The GTF starts with identifying feasible interventions for improving the energy efficiency of the walk-up apartment buildings. We based our GTF on the triple bottom line: planet, profit, and people, a framework developed by Elkington with three aspects: environmental, social, and financial, to evaluate performance from a comprehensive perspective. The triple bottom line planet, profit, and people is employed as the basic structure of the choice matrix for interventions from which design alternatives can be composed. 
Planet, in the GTF, refers to a cluster of technical interventions that can be employed to improve the energy efficiency and indoor quality of the apartments. If the building skin is refurbished and air tightness provided, then two problems will appear: The ventilation will not work appropriately, and because the noise outside is reduced, tenants experience more noise between apartments. According to preliminary research by housing associations, moisture and noise are two main problems in relation to refurbishing the skin of the building. The indoor climate of the apartments must be treated as an integrated healthy phenomenon with heat, fresh air, and low noise level. For this reason, we treat these three aspects as one intervention.

Profit in the GTF refers to a cluster of interventions that deal with the investment of housing associations (and in the end the rent of the tenants). When it is possible to extend the building or enlarge the units on the roof or garden side, then housing associations make more profit and have more possibilities to invest in the expensive adaptions of their housing stock.

People in the GTF refer to a cluster of socio-cultural interventions related to the functional and cultural heritage qualities. By regulation, 70 percent of the tenants must agree with the deep renovation. These blocks have a narrative value for their inhabitants. Of course, sometimes adaptions must be done to improve the quality of the building. Using a cultural and architectural value assessment, the different parts of the buildings were given a positive, indifferent, or negative value. Preliminary research showed the importance of refurbishing and/or replacing the kitchen, bathroom, and toilet areas. Spaces on the garden side and connected to a shallow balcony. This area is lacking service and storage space.

\subsection{Intervention of Design Case VAM Walk-Up Apartment Buildings Utrecht (Figures 6-8)}

The VAM walk-up apartment building, constructed between 1960 and 1964, Camera Obscura in the neighbourhood Overvecht in Utrecht, is used as design case. This apartment building has floorplan type E3, and a characteristic post war façade with and assemblage of dry prefabricated construction components as concrete façade elements and window frames. The concrete façade elements and balconies are in excellent condition; the window frames were already replaced in seventieths and are in a bad condition and need to be replaced once more. The brick façade on the ground floor near the storage space is in a bad condition. In line with planet, profit and people all the interventions are categorized by planet, profit, and people. With each intervention, the consumer has two or three options in the questionnaires.

Planet: energy efficiency and improved indoor quality apartments.. The focus in this GTF is energy efficiency and not circular construction or renovation techniques. However, in the designs alternatives, we chose materials and techniques with a low $\mathrm{CO}_{2}$ footprint (with PV panels as exception). With the LCC and renovation expenses, we took account of circular use of techniques and material according the method that was developed.

1. Reduce energy demand in relation to heating and/or cooling. By insulation and air tightness of the skin of the building: applying low temperature heating (LTH) $50{ }^{\circ} \mathrm{C}$, improved ventilation with natural inlet and mechanical outlet with $\mathrm{CO}_{2}$ and moisture detection, and insulation level label B or more. Energy used for domestic hot water or electricity is not taken into account.

2. Noise reduction between the apartments. As consequence of the new air tightness of the façade, street noise is disappearing, but noise between apartments is now clearly recognized by inhabitants. Noise is to be reduced by applying a floating floor. However, a floating floor is usually constructed in an uninhabited apartment.

3. Use renewable energy. As pointed out, the aim of energy efficiency is carbon neutrality by 2050 . In some neighbourhoods, there is the possibility of a heat network. For this reason, we only have taken renewable energy systems into account that are related to the apartment building: photovoltaic panels for electricity and solar collector for domestic hot water. 
Profit: the strategy of housing associations' is to provide affordable apartments. Their main strategy is to make more buildings by extending or adding apartments. More floor space means more rent/income of a housing association, usually over a period of 30 years. Expensive interventions that bring quality are financed in this way.

4. Add floor space to apartments. More floor space means more income for housing associations and often more quality in the apartments. Furthermore, there is an opportunity to use that space partly as new service space, pipes, and ducts. One can adapt the balcony on the garden side to glass-covered greenhouse or create a new greenhouse on the garden side.

5. Refurbish the storage space to a visual open collective space. Create new secure and open collective storage space on the ground floor. Social security is an important issue in postwar neighborhoods; visual closed storage spaces on the ground floor are not acceptable anymore. Furthermore, new visual open storage spaces are connecting points of electric bicycles and scoot mobiles.

6. Add new apartments in the building. More apartments mean more income for housing associations. However, there is also a lack of small and accessible apartments for older and handicap people in postwar neighbourhoods. Current functions are storage space and bedrooms and storage of the apartments of the 1e floor. Intervention is to replace these functions with four small or two middle units for older or handicapped people, and to replace storage space with garden as protected collective bicycle storage and electricity to provide energy to scoot mobiles and electric bicycles.

7. Change accessibility of the apartments. Add an elevator and a gallery on the garden side, and remove the old stair well and add more floor space. Apartments will be extended, and housing associations will have more income.
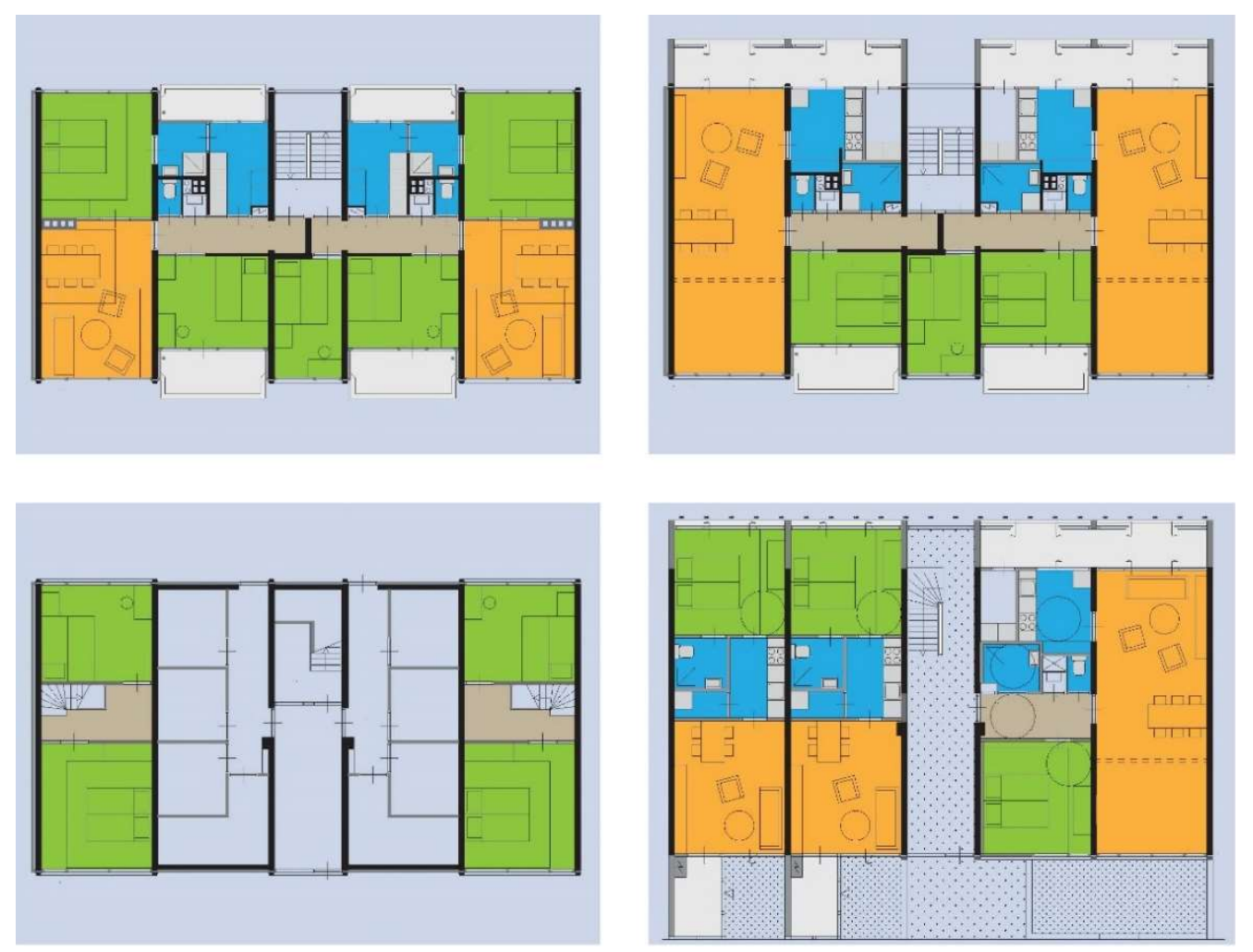

Figure 6. VAM walk-up apartment building (1960) with type E3 floorplan. Top left: original plan 2e, $3 e$, and $4 \mathrm{e}$ floors. Bottom left: original ground floor. Top right: new plan $2 \mathrm{e}, 3 \mathrm{e}$, and $4 \mathrm{e}$ floors. Bottom right: new plan ground floor. Drawing Leo Oorschot. 

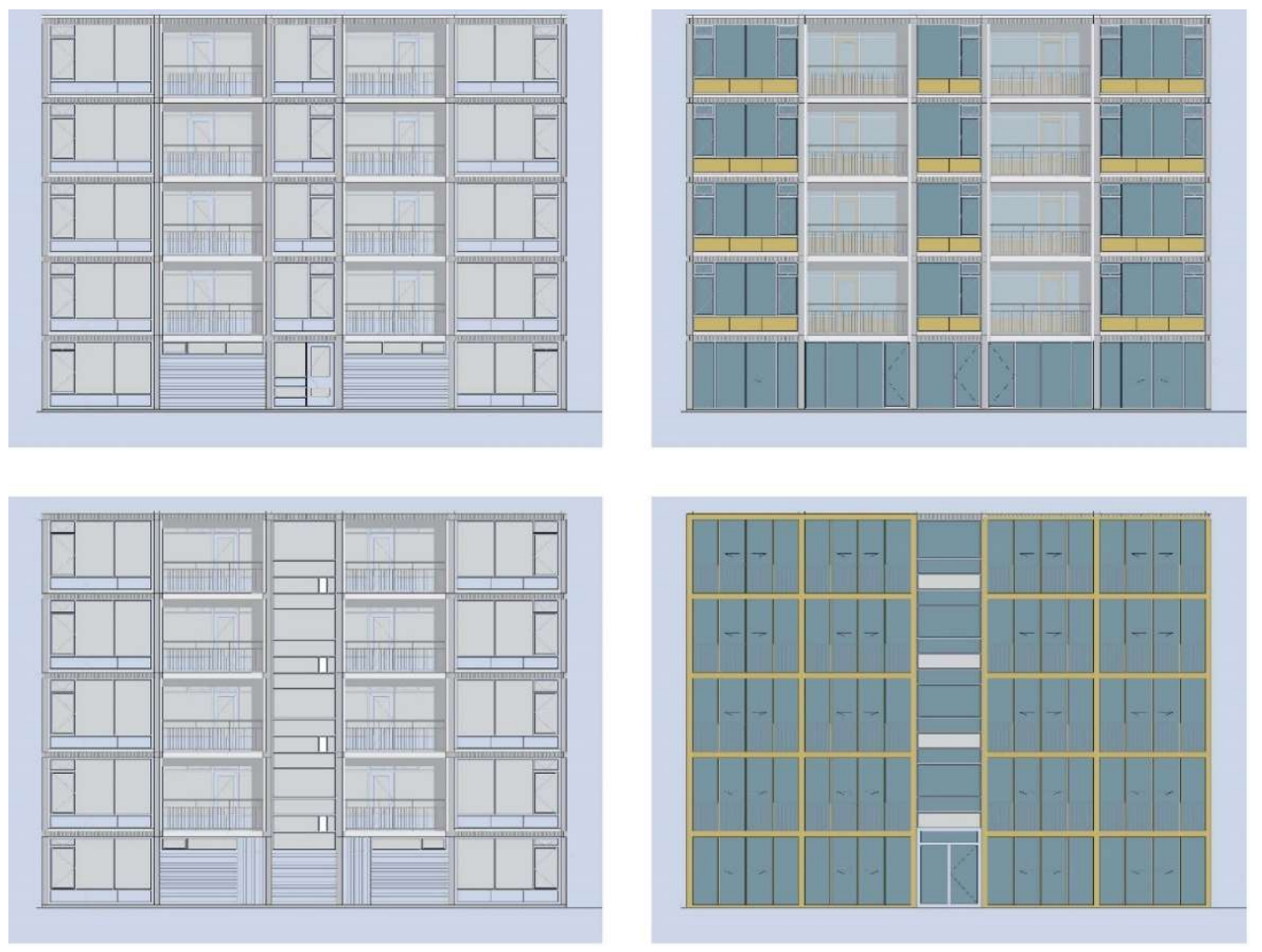

Figure 7. VAM walk-up apartment building (1960) with characteristic façade of dry assemblage of prefabricated construction components as concrete façade elements and window frames. Top left: original street façade; below left: original garden façade. Top right: adaptions on in the new design; below right: glass covered balcony and extension.

People: socio-cultural values, ambition of an attractive and affordable apartment. According to Dutch law, 70 percent of the tenants must agree with the refurbishment. For this reason, housing associations must convince tenants to support renovations, especially regarding quality in the apartment. Furthermore, municipalities and tenants must be convinced that a change in the façade will bring more quality.

8. Improve legibility architecture street façade. Adapt the window frames in three variations: original, half-open, and open. Changing the ground floor façade to an open façade.

9. Adapting kitchen, bathroom, and toilet area. Extending and/or redesigning this area with new storage/service space and better functional connections.

10. New spatial arrangement living and bedrooms. Three options. Original floorplan with living with and two bedrooms. Single person arrangement (1 bedroom and big living), big family arrangement ( 3 bedrooms, small living).

We summarized the design variations and different interventions in a choice matrix and visualized in questioners list. Housing associations in Den Haag and Amsterdam used these questionnaire lists to provide quantitative data about consumer preferences. 


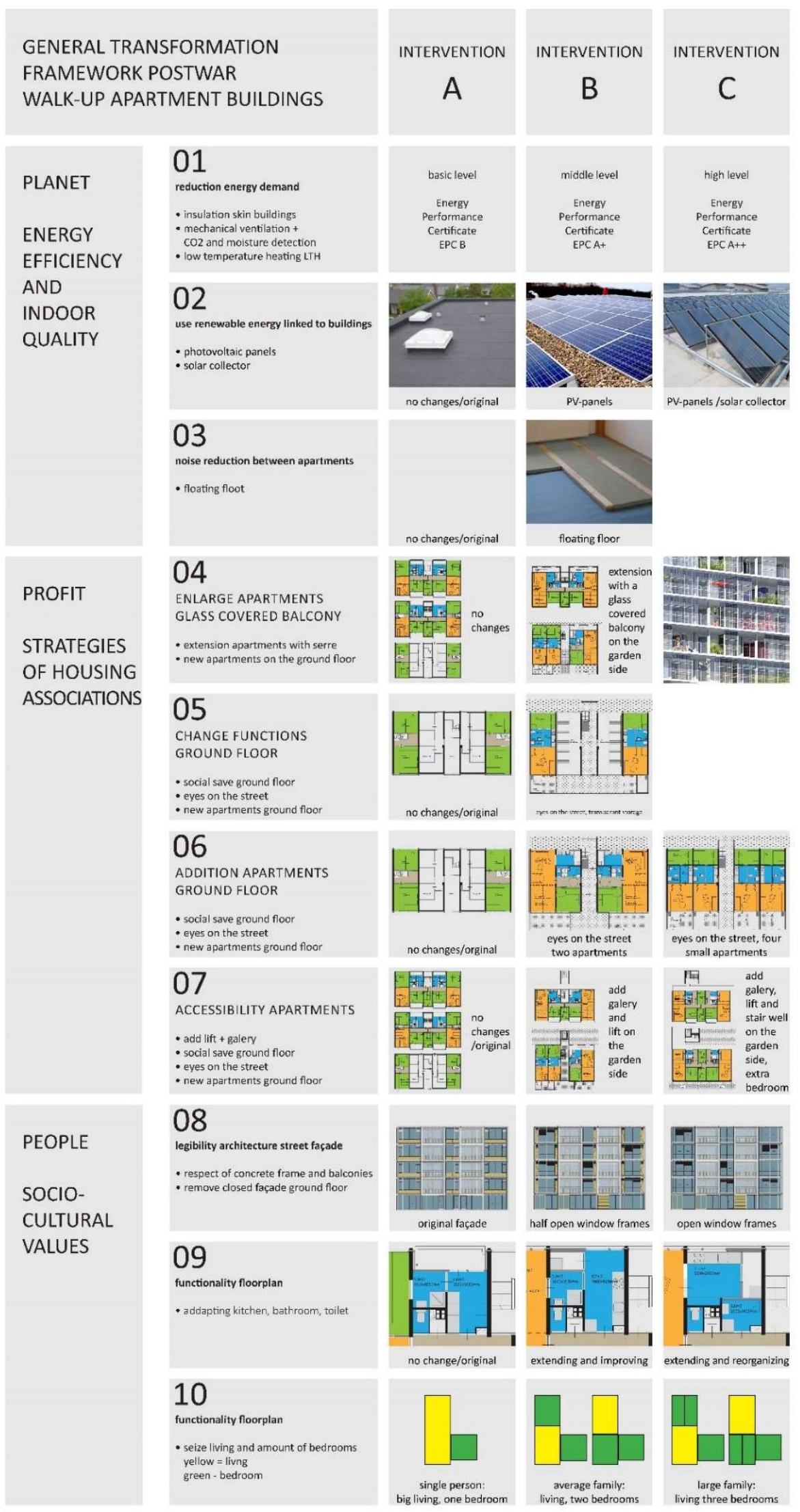

Figure 8. Design variations of the VAM walk-up apartment building are categorized in a choice matrix, GTF, for option appraisal. The most common postwar floorplan type E3 designed by the architect E.F. Groosman is used. Graphic by Leo Oorschot. 


\subsection{Reflections of Architects and Housing Associations on the GTF}

Housing associations from Amsterdam, Rotterdam, Den Haag, and Utrecht, and renovation architects, were represented in two workshops, with a test case, on the GTF and results from the questionnaire of the design case. The debate was on the value and priority of the interventions according to the GTF. The following design interventions were preferred by housing association and renovation architects and were based on past experience and listed in succession of importance:

1. Extending or enlarging the building, and making more apartments, for example, an enclosed glass balcony on the garden side. More square meters imply a densification of the neighbourhood, more income for housing associations, lower construction costs, and more possibilities to invest in interventions. Suggestions are to make accessible apartments on the ground floor, to make extensions on the garden side, and to make extensions on the roof.

2. Reducing energy demand by insulating the skin of the building to allow for a low or middle temperature heating system in the apartment, combined with mechanical ventilation. It is possible to apply different types of heat pumps in the future.

3. Improving the outdated kitchen, bathroom, toilet, and storage areas. This is important for the quality of the apartments and allows for the construction of new services systems, fuse box, and shafts.

4. Noise reduction between units; although they are in inhabited state, this is a complex issue to resolve. Technically, the most effective solution would be a floating floor, but is impossible in a fully furnished apartment. A solution could be insulation in the ceiling, i.e., a suspended ceiling.

5. Complex heat systems and installations with renewable energy in the buildings are too expensive and complicated for tenants. Their advice here is to keep it simple and make it collective instead individual. Housing associations are currently using individual heating systems based on natural gas. In the future, it is likely that all apartments will be connected to a heat network of $70{ }^{\circ} \mathrm{C}$ and will use external renewable energy.

The following pressing problems have been identified by the partnering housing associations: the lack of new apartments and stagnation of mobility of tenants on the housing market in urban regions, and the lagging of municipalities about the choice of a heat distribution system for each neighbourhood in the future. As pointed out, the most likely option for the postwar housing stock is a regional open heat network $\left(70^{\circ} \mathrm{C}\right)$ and walk-up apartment building upgraded to label $\mathrm{B}$ or more.

\section{Conclusions: Balancing Sustainability and Cultural Values in Energy Efficient Renovation}

This research with the GTF and reflections dealt with balancing sustainability and cultural values in energy efficient renovation of postwar walk-up apartment buildings. In this balance between choices, it appears that tenants prefer the existing street façade and floor plan. The adaptions chosen by tenants were just to bring more quality to the existing floorplans. There was a new interpretation of the outdated kitchen-bathroom-toilet-area and the shallow balcony on the garden side was changed to a bigger glass covered balcony on the garden side. According to housing associations, tenants are indifferent to the addition of expensive galleries and elevators, newly designed facades, or even new floor plans, and prefer simple adaptations to make their dwelling more comfortable, but also to make sustainability visible, such as PV-panels or solar collector, instead of better EPC performance. Furthermore, the research showed that label B, in combination with regional and open heat network, is the most likely approach to provide heat. Even tough carbon neutrality is a still a promise because of the use of EfW as source. In this case, it is not necessary to change the façade radically.

The most important conclusion is that deep renovation of postwar apartment buildings with respect to architectural values is possible in a feasible way on the street façade. Regarding minor adaptions on the street façade, label B is possible. Adaptions on the façade on the garden side are likely because of user preference, extending space, adding service space, and insulation of a part of the 
façade. Because the difference between postwar subtypes 3 and 4 was mainly the façade, we could draw this same conclusion for all postwar walk-up apartment buildings.

This conclusion is translated in workshops with housing associations and renovation architects in a strategy and visualized in a Roadmap 2018-2050, as Figure 9 shows. The best and most feasible approach is to adapt postwar walk-up apartment buildings in inhabited state in three intervention steps.

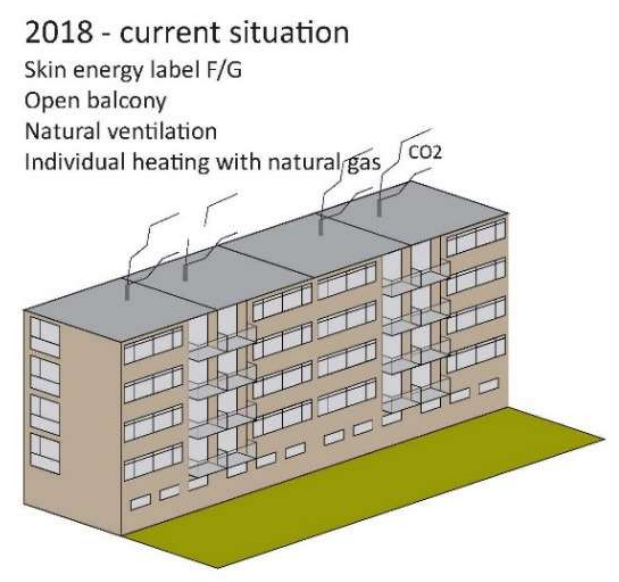

Intervention B - renovation uninhabited state After tenant left apartment: Sound insulation apartment Refurbish kitchen, bathroom, toilet

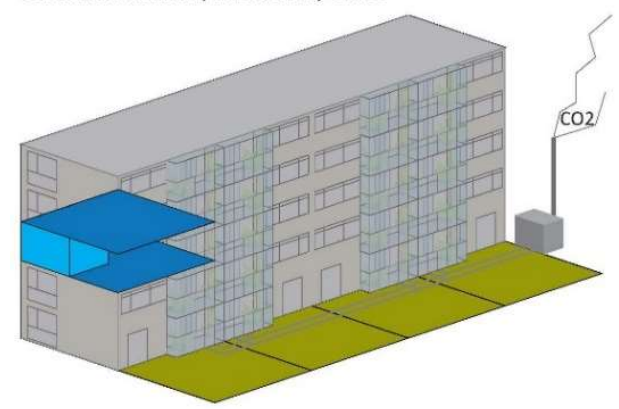

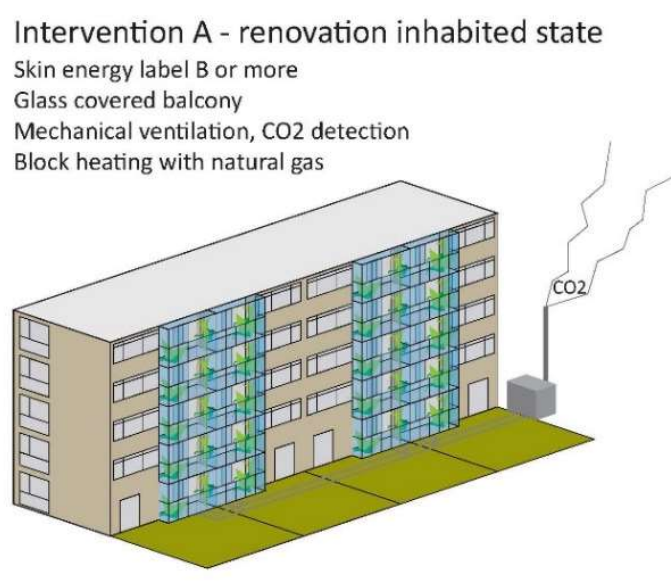

Intervention C - 2050

From natural gas to renewable energy, two options heating: 1 All Electric + Seasonal thermal energy storage $\left(50^{\circ} \mathrm{C}\right.$ or $\left.70^{\circ} \mathrm{C}\right)$ 2 Regional open heat network $\left(70^{\circ} \mathrm{C}\right)$

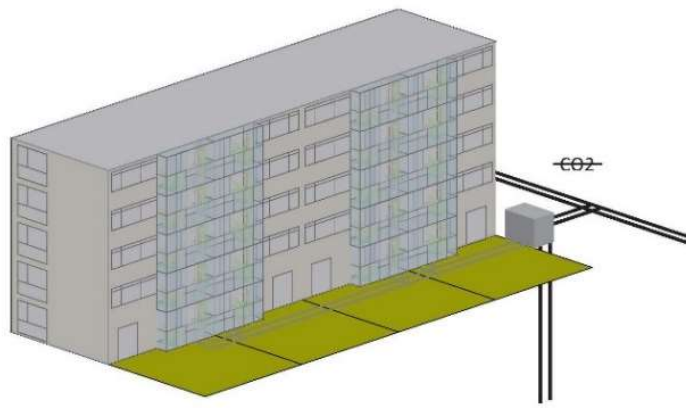

Figure 9. Roadmap 2018-2050 shows the interventions in consumer preferences in balancing carbon neutrality and cultural values in postwar walk-up apartment buildings. Graphic by Leo Oorschot.

Intervention A-Planet: building renovation in inhabited state. Adapting the building skin and reducing the energy demand, assuming label B or A. Change individual heating to collective block heating with natural gas, with a service plant in the basement or garden. Change natural ventilation to mechanical ventilation with $\mathrm{CO}_{2}$ and moisture detection. Add a glass covered balcony on the garden side with new service space, pipes, and ducts. Replace the fuse box. (This step is the most difficult step because of the confrontation of tenants with a noisy construction process). There are usually vacant apartments or portable cabins available for a few days, if necessary. Profit: Housing associations have the possibility of adding dwellings to postwar buildings on the ground floor, replacing the storage space and apartments on the roof. People: Tenants could choose visible sustainability measures such as a solar collector or PV-panels on the roof.

Intervention B-People: apartment renovation or adaption in uninhabited state, in which a tenant moves house. Improve or redesign the kitchen, bathroom, toilet, and storage. Make a floating floor and reduce noise between apartments. Profit: New tenants pay rent according to a new rating system, which was introduced with the Housing Act of 2015. On the other hand, a tenant with a middle-level income who left the dwelling paid more rent than the regulations required from low-income tenants. 
Intervention C-Planet: exchange heat and energy source when the layout of a regional open heat network in the neighbourhood is ready, or a smart grid with enough capacity is available. Then, connect the building to the distribution network and disconnect natural gas.

Author Contributions: L.O. and L.S. contributed to the overview, and building, technical, and architectural historic research; T.K. took care of the energy calculations, and T.d.J. was accountable for calculating construction cost, rent, and energy cost. S.E.M. and C.v.O. were responsible for parts on consumer preferences; V.G., T.A., and W.d.J. supervised the research.

Funding: This work is part of the research program Research through Design, project number 14569, which is (partly) financed by the Netherlands Organization for Scientific Research (NWO) and Taskforce for Applied Research SIA.

Acknowledgments: Beyond the Current research through design project of the Delft University of Technology and HU University of Applied Sciences Utrecht between May 2016 and May 2018 was about user preference-tested design solutions for cultural values and energy-efficient walk-up apartment building renovations of inter- and postwar buildings in Dutch city regions. Research was done with housing associations, institutes, and experienced renovation architects. From Delft University of Technology were Vincent Gruis (chair: Housing Management), Thijs Asselbergs (chair: architectural engineering), and Wessel de Jonge (chair: Heritage \& Design) involved.

\section{NWO \begin{tabular}{l|l} 
Applied and \\
Engineering Sciences
\end{tabular}}

Conflicts of Interest: The authors declare no conflict of interest. The founding sponsors had no role in the design of the study; in the collection, analyses, or interpretation of data; in the writing of the manuscript; or in the decision to publish the results.

\section{References}

1. Buildings Performance Institute Europe (BPIE). Europe's Buildings under the Microscope; Buildings Performance Institute Europe: Brussels, Belgium, 2011.

2. Engergieprestatie-BENG. 2017. Available online: https://www.rvo.nl/onderwerpen/duurzaam-ondernemen/ gebouwen/wetten-en-regels-gebouwen/nieuwbouw/energieprestatie-beng? (accessed on 2 December 2017).

3. Sociaal-Economische Raad (SER). Energieakkoord Voor Duurzame Groei; Sociaal-Economische Raad: The Hague, The Netherlands, 2013.

4. $\quad$ Aedes. Woonagenda 2017-2021; Aedes: Den Haag, The Netherlands, 2017.

5. Sijpheer, N.C.; Borsboom, W.A.; Opstelten, I.J. Results from first 'netzero energy' projects in the Netherlands. In Proceedings of the Sustainable Built Environment: Transition Zero-The Utrecht SBE16 Conference, Utrecht, The Netherlands, 7-8 April 2016; pp. 43-52.

6. Brinksma, H. Toekomstbestendig Renoveren; Architecture and the Built Environment: Delft, The Netherlands, 2017.

7. One Stop Shop. From Demonstration Projects Towards Volume Market: Innovations for Sustainable Renovation. 2017. Available online: http:/ / www.one-stop-shop.org/ (accessed on 2 December 2017).

8. Bertoldi, P.; Hirl, B.; Labanca, N. Energy Efficiency Status Report 2012; Report EUR 25405 EN; EU: Brussels, Belgium, 2012.

9. Rijksdienst voor het Cultureel Erfgoed. Richtlijnen Bouwhistorisch Onderzoek: Lezen en Analyseren van Cultuurhistorisch Onderzoek; Rijksdienst voor het Cultureel Erfgoed, Stichting Bouwhistorie Nederland, Vereniging Nederlandse Gemeenten, Atelier Rijksbouwmeester, Rijksgebouwendienst: Den Haag, The Netherlands, 2009.

10. Rijksdienst voor het Cultureel Erfgoed. Eenheid en Verscheidenheid: Een Zoektocht naar een Integrale Cultuurhistorische Waardestelling van het Materiële Erfgoed; Rijksdienst voor het Cultureel Erfgoed: Amersfoort, The Nederland, 2014.

11. Municipality of Amsterdam. De Schoonheid van Amsterdam 2013. Welstandsnota Gemeente Amsterdam; City of Amsterdam: Amsterdam, The Netherlands, 2013.

12. Argiolu, R.; van Beckhoven, E.; Bolt, G.; van Dijken, K.; Engbersen, G.; Engbersen, R.; van Kempen, R.; Koffijberg, J. Bloei en Verval van Na-Oorlogse Wijken; I.o. Nicis Institute: Den Haag, The Netherlands, 2008.

13. Hochstenbach, C. Inequality in the Gentrifying European City; University of Amsterdam: Amsterdam, The Netherlands, 2017. 
14. Havinga, L.C.; Colenbrander, B.J.F.; Schellen, H.L. Relating sustainability indicators to the refurbishment of the existing building stock. In Proceedings of the 30th International PLEA Conference Sustainable Habitat for Developing Societies, Ahmabedad, India, 16-18 December 2014.

15. Van Krugten, L.T.F.; Hermans, L.M.C.; Havinga, L.C.; Roders, A.R.P.; Schellen, H.L. Raising the energy performance of historical dwellings. Manag. Environ. Qual. Int. J. 2016, 27, 740-755. [CrossRef]

16. Elkington, J. Cannibals with Forks: The Triple Bottom Line of 21st Century Business; New Society Publishers: Gabriola, BC, Canada, 1998.

17. Morgen, M.; Dannemand Frost, E.; Østergaard Jørgsen, T.; Braae, E.; Høi, A. Bygningskultur og Bevaringsværdier. 1940'erne og 1950'ernes Murede Boligbebyggelser; Tarm Bogtryk: Tarm, Denmark, 2015.

18. Bech-Danielsen, C.; Heiselberg, P.; Høi, A. Renoveringsguide Kvaliteter, Udfordringer og Anbefalinger. 1940'erne og 1950'ernes Murede Boligbebyggelser; Tarm Bogtryk: Tarm, Denmark, 2015.

19. Oorschot, L.; Konstantinou, T. Retrofit for continuity! Heritage, user preferences and gentrification: Refurbishment and sustainability of tenement apartment blocks in Dutch cities from the interbellum and the post war period. In AMPS Proceedings Series 9. Living ANS Sustainanbility: An Environmental Critique of Design E Building Practice, Locally and Globally; Cairns, G., Ed.; London South Bank University: London, UK, 2017; pp. 44-52.

20. Oorschot, L. Is all-electric an option? About retrofitting and gentrification of pre-war tenement apartment blocks in Amsterdam. In AMPS Proceedings Series 10. Cities, Communities and Homes: Is the Future Liveable? Cairns, G., Tracada, E., Eds.; Liverpool University Derby: Derby, UK, 2018; pp. 569-578.

21. Yin, R. Case Study Research: Design and Methods; Applied Social Research Methods Series; SAGE Publications: Thousand Oaks, CA, USA, 1994; Volume 5.

22. Groat, L.; Wang, D. Architectural Research Methods; John Wiley \& Sons: Hoboken, NJ, USA, 2002.

23. Godin, D.; Zahedi, M. Aspects of Research through Design: A Literature Review. In DRS 2014: Design's Big Debates; Lim, Y.-K., Niedderer, K., Redström, J., Stolterman, J., Valtonen, A., Eds.; Umeå Institute of Design: Umeå, Sweden, 2014; pp. 1667-1679.

24. De Vreeze, N. Woningbouw, Inspiratie \& Ambities. Kwalitatieve Grondslagen van de Sociale Woningbouw in Nederland; Nationale Woningraad: Almere, The Netherlands, 1993.

25. De Klerk, L. 'Mooi werk' Geschiedenis van de Maatschappij voor Volkswoningbouw; nai010 uitgevers: Rotterdam, The Netherlands, 1999.

26. Tellinga, J. De Grote Verbouwing. Verandering van Naoorlogse Woonwijken; nai010 uitgevers: Rotterdam, The Netherlands, 2004.

27. Stissi, V. Amsterdam, het Mekka van de Volkshuisvesting, Sociale Woningbouw 1909-1942; nai010 uitgevers: Rotterdam, The Netherlands, 2007.

28. Kleinegris, R.; van der Burg, F.; de Leeuwe, J. Compact en Harmonisch. Sociale Woningbouw in Den Haag 1850-2015; Stokerkade Cultuurhistorische Uitgeverij: Amsterdam, The Netherlands, 2016.

29. Oorschot, L. Conflicten over Haags Stadsbeelden. Van Willemspark tot Spuiforum; Architecture and the Built Environment, Delft University of Technology: Delft, The Netherlands, 2014.

30. Van Wijngaarden, A.; Hooykaas, F.; Groenendijk, P.; Reijndorp, A. Rotterdam Woont. Atlas van de Rotterdamse Woningbouw 1840-2015; Uitgeverij Thoth: Bussum, The Netherlands, 2017.

31. Broekhuisen, P.; Buurman, M.; ten Cate, G.; Camp, D.; Galema, W.; Groenedijk, P.; Hooimeijer, F.; Jansen, B.; Ruitenbeek, J.; Valentijn, D. De Wederopbouw: Haagse gids voor Architectuur en Stedenbouw in de Periode 1945-1965; De Nieuwe Haagsche: Den Haag, The Netherlands, 2002.

32. Steenhuis, M.; Meurs, P.; Emmerik, J.; Plomp, M.; Voerman, L. 10 Cultuurhistorisch Onderzoek en Ruimtelijke Analyse Utrecht Na Oorlogse Wijken: Overvecht; Steenhuis stedenbouw/landschap I Urban Fabric: Schiedam, The Netherlands, 2006.

33. Blom, A. Atlas van de Wederopbouw Nederland 1940-1965; nai010 uitgevers: Rotterdam, The Netherlands, 2013.

34. Steenhuis, M.; Meurs, P.; van Rossem, V.; Schilt, S.; Voerman, J.; Walda, M. De Nieuwe Grachtengordel; Uitgeverij Thoth: Bussum, The Netherlands, 2017.

35. CBS Stateline. 2017. Available online: https://opendata.cbs.nl/statline/\#/CBS/nl/ (accessed on 12 December 2017).

36. Dienst der Stadsontwikkeling en Volkshuisvesting; Suyver, H.E. Enige Grondslagen voor de Stedenbouwkundige Ontwikkeling van 's-Gravenhage; Hega: The Hague, The Netherlands, 1948.

37. Voorbeeldboek. Afbeeldingen van Arbeiderswoningen met Rijkssteun Gebouw (1905-1909); Department of Labor in The Hague: The Hague, The Netherlands, 1909. 
38. Voorbeeldboek. Album Bevattende een 50 tal Woningtypen voor met Rijksvoorschot te Bouwen Woningen; Department of Labor in The Hague: The Hague, The Netherlands, 1920.

39. Berlage, H.P.; Keppler, A.; Kromhout, W.; Wils, J. Arbeiderswoningen in Nederland_Vijftig met Rijkssteun, Onder Leiding van Architecten Uitgevoerde Plannen, met de Financieele Gegevens; W.L. \& J. Brusse's Uitgevers-Maatschappij: Rotterdam, The Netherlands, 1921.

40. Van der Wal, L. Beter Wonen. Gedenkboek, Gewijd aan het Werk der Woningbouwvereenigingen in Nederland, Uitgegeven ter Gelegenheid van het 25-Jarig Bestaan van den Nationalen Woningraad, Algemeenen Bond van Woningbouwvereenigingen; De Arbeiderspers: Amsterdam, The Netherlands, 1938.

41. Keppler, A. Gemeentelijke Woningbouw; Amsterdamse Woningraad: Amsterdam, The Netherlands, 1913.

42. Voorbeeldboek. Woningbouw van Gemeentewege Amsterdam 1914; Municipality of Amsterdam: Amesetrdam, The Netherlands.

43. Keppler, A.; Wibaut, F. De Gemeente en de Volkshuisvesting; Bibliotheek voor Gemeentepolitiek; "Ontwikkeling"; Municipality of Amsterdam: Amsterdam, The Netherlands, 1925.

44. Bakker Schut, P. De Volkshuisvesting te 's-Gravenhage 1914-1939. Vijf en Twintig Jaar Overheidsbemoeiing met de Volkshuisvesting; Samson: Alphen aan de Rijn, The Netherlands, 1939.

45. Rotterdam Woont. Systematische Documentatie van 150 Rotterdamse Woningbouwprojecten. 2017. Available online: https: / rotterdamwoont.nl/ (accessed on 12 December 2017).

46. Groenendijk, P.; Hooykaas, F.; Wijngaarden, A.; van Reijndorp, A. Rotterdam Woont. Atlas van de Rotterdamse Woningbouw 1840-2015; Uitgeverij Thoth: Bussum, The Netherlands, 2016.

47. Vriend, J.J.; Arendzen, G. Bouwkunde Hand-en Studieboek voor den Bouwkundige. Deel 1 E 2; Kosmos: Amsterdam, The Netherlands, 1943.

48. Koffijberg, J. Kwaliteit met Beleid: Voorschriften en Wenken ter discussie, Deelstudie Vijftig Jaar DGVH; Delft University Press: Delft, The Netherlands, 1997.

49. Priemus, H.; Van Elk, R.S.F.J. Niet-traditionele Woningbouwmethoden in Nederland; Samson uitgeverij \& Stichting Bouw Research: Alphen aan den Rijn, The Netherlands, 1970.

50. Lijbers, R.; Thijssen, C.; Westra, H. Woningvoorraad 45-76; Delftse Universitaire Pers: Delft, The Netherlands, 1984; pp. 13-14.

51. Thijssen, C.; Meijer, C.J. Bouwconstructieve Analyse van Naoorlogse Meergezinshuizen in de Non-Profit Huursector 1946-1965; Delftse Universitaire Pers: Delft, The Netherlands, 1988.

52. Thijssen, C. Technische Kwaliteit van Etagewoningen; Delftse Universitaire Pers: Delft, The Netherlands, 1990.

53. Bouwhulp Groep. Documentatie Systeemwoningen '50-'75; Bouwhulp Groep \& Platform 31: Eindhoven, The Netherlands, 2013.

54. Eigen Haard. Kwaliteitsrichtlijnen Nieuwbouw Handleiding voor Intern, Architecten en Adviseurs; Eigen Haard: Amsterdam, The Netherlands, 2015.

55. Eigen Haard. Ontwerpeisen Portiekwoningvoorraad Eigen Haard Handleiding voor Projectontwikkelaars en Adviseurs; Eigen Haard: Amsterdam, The Netherlands, 2016.

56. Eigen Haard. Standaard Materialenlijst Eigen Haard; Eigen Haard: Amsterdam, The Netherlands, 2015.

57. Warmtenet Region Amsterdam. 2018. Available online: http://energiekaart.net/warmtenet-regioamsterdam/ (accessed on 2 March 2018).

58. Provincie Zuid-Holland. 2018. Available online: https://www.zuid-holland.nl/onderwerpen/energie/ energieagenda/ (accessed on 2 March 2018).

59. Warmtenetwerk Utrecht. 2018. Available online: http://energiekaart.net/initiatieven/warmtenetwerkutrecht/ (accessed on 2 March 2018).

60. Overheid. 2018. Available online: https://zoek.officielebekendmakingen.nl/dossier/34723 (accessed on 2 March 2018).

61. Ministerie van Economische Zaken. Kamerbrief Warmtevisie; Brief aan de Tweede Kamer: The Hague, The Netherlands, 2015.

62. EcoRys. Evaluatie Warmtewet en Toekomstig Marktontwerp Warmte; i.o. Ministerie Economische Zaken: Rotterdam, The Netherlands, 2016.

63. CE Delft. Een Klimaatneutrale Warmtevoorziening voor de Gebouwde Omgeving-Update 2016; i.o. GasTerra, Gasunie: Delft, The Netherlands, 2016.

64. CE Delft. Op weg naar een Klimaatneutrale Gebouwde Omgeving 2050; i.o. GasTerra: Delft, The Netherlands, 2015. 
65. Planbureau voor de Leefomgeving. Toekomstbeeld Klimaatneutrale Warmtenetten in Nederland; PBL: Den Haag, The Netherlands, 2017.

66. CE Delft. Scenario's voor de Warmtetransitie in Den Haag; Gemeente Den Haag: Delft, The Netherlands, 2017.

67. Muncipality of Den Haag. Programmaplan Energietransitie. Concept Versie 30 Januari 2018; Municipality of Den Haag: The Hague The Netherlands, 2018.

68. DWA. Verduurzaming Warmtevoorziening Bestaande Woningen in Statenkwartier en Vogelwijk Den Haag; DWA: Bodegraven, The Netherlands, 2017.

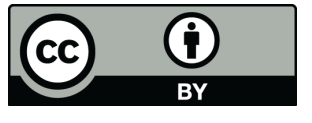

(C) 2018 by the authors. Licensee MDPI, Basel, Switzerland. This article is an open access article distributed under the terms and conditions of the Creative Commons Attribution (CC BY) license (http://creativecommons.org/licenses/by/4.0/). 